Citation: G. Parrella, E. Troiano, A. Stinca, M. I. Pozzi (2021) Molecular and serological detection of Parietaria mottle virus in Phytolacca americana, a new host of the virus. Phytopathologia Mediterranea 60(1): 101-104. doi: 10.36253/phyto-12207

Accepted: January 27, 2021

Published: May 15, 2021

Copyright:@2021 G. Parrella, E. Troiano, A. Stinca, M. I. Pozzi. This is an open access, peer-reviewed article published by Firenze University Press (http:// www.fupress.com/pm) and distributed under the terms of the Creative Commons Attribution License, which permits unrestricted use, distribution, and reproduction in any medium, provided the original author and source are credited.

Data Availability Statement: All relevant data are within the paper and its Supporting Information files.

Competing Interests: The Author(s) declare(s) no conflict of interest.

Editor: Arnaud G Blouin, New Zealand Institute for Plant and Food Research, Auckland, New Zealand.
New or Unusual Disease Reports

\section{Molecular and serological detection of Parietaria mottle virus in Phytolacca americana, a new host of the virus}

\author{
Giuseppe PARrella ${ }^{1, *}$, Elisa TroianO ${ }^{1}$, Adriano STINCA ${ }^{2}$, Maria \\ ISABELLA POZZI ${ }^{1}$ \\ ${ }^{1}$ Institute for Sustainable plant Protection of National Research Council (IPSP-CNR), \\ Piazzale Enrico Fermi 1, 80055 Portici (NA), Italy \\ ${ }^{2}$ Department of Environmental, Biological and Pharmaceutical Sciences and Technolo- \\ gies, University of Campania Luigi Vanvitelli, Via Vivaldi 43, 81100 Caserta, Italy \\ ${ }^{\star}$ Corresponding author: giuseppe.parrella@ipsp.cnr.it
}

Summary. Parietaria mottle virus (PMoV) is an emerging virus in Mediterranean countries, responsible for severe disease in tomato and pepper crops in the field and protected cultivation. The principal wild reservoir of PMoV is Parietaria officinalis, and only few additional wild plants have been described as natural reservoirs of the virus. During field survey in southern Italy, several plants of Phytolacca americana showing virus-like symptoms were collected. Serological and molecular assays showed that these plants were infected by PMoV. Sequence comparison of the movement protein gene of the PMoV isolate from $P$. americana showed the greatest similarity to the corresponding sequence from tomato plants growing nearby. These results indicate that $P$. ameriacana is a new natural host of $\mathrm{PMoV}$, and further investigation is warranted to establish the potential of this host as reservoir of the virus in the field.

Keywords. PMoV, alien species, American pokeweed, natural host, emerging viruses.

\section{INTRODUCTION}

Phytolacca americana L. (Phytolaccaceae), commonly known as "American pokeweed", "pokeweed" or "dragonberries", is a poisonous perennial geophyte herb native to North America. It was introduced in Europe where it is invasive in many countries, including Italy (Galasso et al., 2018). This neophyte plant mainly spreads in anthropic and disturbed environments (Stinca and Motti, 2017; Bonanomi et al., 2018). In July 2020, during a survey of tomato virus diseases in southern Italy (Campania region), several individuals of $P$. americana were noticed showing virus-like symptoms, comprising mosaic, chlorotic spots and lines and leaf distortions (Figure 1). The detected plants were growing close to a family garden, located in the Sorrento peninsula, were Parietaria mottle virus $(\mathrm{PMoV})$ was detected in a local variety of tomato with high incidence. Distances from pokeweed plants to the tomato plants ranged between 5 to $20 \mathrm{~m}$. The presence of thrips individuals on 


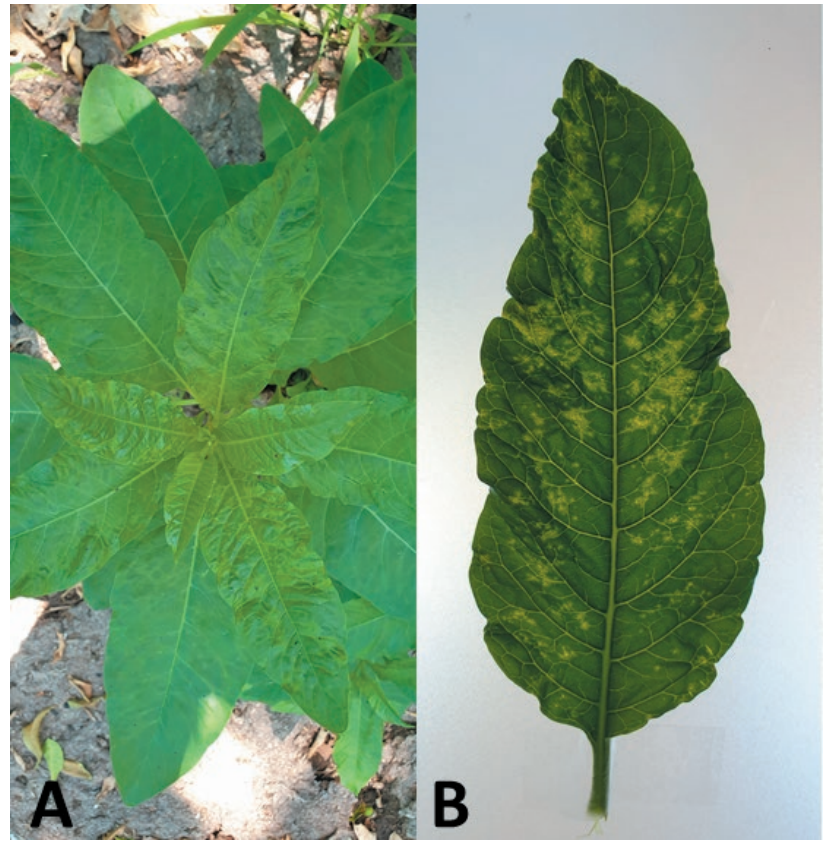

Figure 1. Symptoms associated to Parietaria mottle virus infection in Phytolacca americana L.: (A) mosaic on the apical leaves, and (B) details of symptoms on a leaf.

tomato and pokeweed plants was also observed. Overall, field observations suggested possible implication of $\mathrm{PMoV}$ as the cause of the symptoms observed in pokeweed plants.

\section{MATERIALS AND METHODS}

Leaf-sap from three symptomatic and two asymptomatic $P$. americana plants, and two symptomatic tomato plants, was mechanically inoculated to Chenopodium quinoa Willd., C. amaranticolor (H.J.Coste \& A.Reyn.) H.J.Coste \& A.Reyn., Vigna unguiculata (L.) Walp. 'Black eye' and Nicotiana tabacum L. 'Xanthi nc.'.

The same samples were tested by antigen-coated-plate enzyme-linked immunosorbent assay (ACP-ELISA) with a specific PMoV polyclonal antibody (Lisa et al., 1998), following the procedure of Parrella (2020). In addition, samples were tested by cucumber mosaic virus (CMV) and tomato spotted wilt virus (TSWV)-specific lateral flow (LF) kits (Pocket Diagnostic), since in tomato symptoms induced by $\mathrm{PMoV}$ resembling those induced by CMV and TSWV in single or mixed infections have also been reported (Ramasso et al., 1997; Roggero et al., 2000).

Total RNAs were extracted with the E.Z.N.A. Plant RNA Kit (Omega Bio-tek), and RT-PCR using the PMoV specific primers PMoVMP1a and PMoVMP2b, encompassing the entire $\mathrm{PMoV}$ movement protein (Parrella et al., 2016). Amplicons of the expected size (916 bp) obtained from symptomatic samples were cloned into pGEM-T vector (Promega), and were sequenced at Microsynth Seqlab (Göttingen, Germany). Blast analysis was performed online (http://blast.ncbi.nlm.nih.gov/ Blast.cgi), and fifteen sequences of other PMoV isolates (Table 1) were downloaded and were used to determine

Table 1. Parietaria mottle virus isolates used in the present study.

\begin{tabular}{|c|c|c|c|c|}
\hline Isolate & Host & Geographic origin & Year of collection & Accession No. \\
\hline Phal & Phytolacca americana & Campania, Italy & 2020 & MW248388 \\
\hline 390 & Solanum lycopersicum & Campania, Italy & 2020 & MW456562 \\
\hline $391 \mathrm{~A}$ & Solanum lycopersicum & Campania, Italy & 2020 & MW456563 \\
\hline Sar-1 & Solanum lycopersicum & Sardinia, Italy & 2019 & MN782302 \\
\hline Ruc1 & Diplotaxis tenuifolia & Campania, Italy & 2016 & KX866978 \\
\hline Ruc2 & Diplotaxis tenuifolia & Campania, Italy & 2016 & KX866979 \\
\hline Fri-1 & Capsicum annuum & Campania, Italy & 2015 & LT160068 \\
\hline Fri-2 & Capsicum aпnuиm & Campania, Italy & 2015 & LT160070 \\
\hline Pap-1 & Capsicum annuum & Campania, Italy & 2015 & LT160069 \\
\hline M31A & Solanum lycopersicum & Catalonia, Spain & 2006 & AM182749 \\
\hline $\mathrm{G} 34 \mathrm{H}$ & Solanum lycopersicum & Catalonia, Spain & 2006 & AM182744 \\
\hline $\mathrm{AC} 1$ & Solanum lycopersicum & Catalonia, Spain & 2006 & AM182743 \\
\hline SD2 & Solanum lycopersicum & Catalonia, Spain & 2006 & AM182745 \\
\hline RAMS1 & Solanum lycopersicum & Catalonia, Spain & 2006 & AM182748 \\
\hline So7J & Solanum lycopersicum & Catalonia, Spain & 2006 & AM182746 \\
\hline JBT1 & Solanum lycopersicum & Catalonia, Spain & 2006 & AM182747 \\
\hline CR8 & Solanum lycopersicum & Catalonia, Spain & 2001 & FJ858204 \\
\hline $\mathrm{T} 32$ & Solanum lycopersicum & Piedmont, Italy & 1979 & KT005245 \\
\hline
\end{tabular}


the phylogenetic relationships among them and the pokeweed isolate (named Pha1). Multiple sequence alignment was performed using the ClustalW algorithm of MEGA 6.0 (Tamura et al., 2013), with gap opening penalty of 15 and gap extension penalty of 6.66. A phylogenetic tree was constructed using the neighbor-joining (NJ) method with 1000 bootstrap replicates, and genetic distance was calculated by the Tamura three-parameter model which was determined as the best-fitting model of substitution using MEGA 7.0.

\section{RESULTS AND DISCUSSION}

Inoculated host plants showed the following symptoms after 1 to 3 weeks, consistent with symptoms caused by PMoV (Ramasso et al., 1997; Marchoux et al., 1999): large chlorotic local lesions followed by dieback and wilting in C. quinoa; large chlorotic local lesions followed by mosaic in C. amaranticolor; necrotic local lesions in $V$. unguiculata; and pinpoint necrotic local lesions followed by mosaic, leaf distortions, vein necrosis and necrotic patches on the apical non-inoculated leaves of N. tabacum. PMoV infection in symptomatic hosts was confirmed by RT-PCR. Host plants inoculated with leaf sap of the asymptomatic pokeweed plants showed no symptoms.

PMoV was detected by ACP-ELISA in all symptomatic plants, with an average optical density (O.D.) at 450 $\mathrm{nm}$ of $0.96 \pm 0.60(\mathrm{n}=3)$, and $0.12 \pm 0.03$ for asymptomatic plants $(\mathrm{n}=2)$, after $1 \mathrm{~h}$ of substrate incubation. Tests for the potential additional presence of TSWV and CMV by LF were negative.

The ACP-ELISA results were confirmed with reverse transcription (RT)-PCR. The expected 916 bp fragment was obtained from symptomatic pokeweed (Figure 2) and tomato plants tested, while no amplicon was

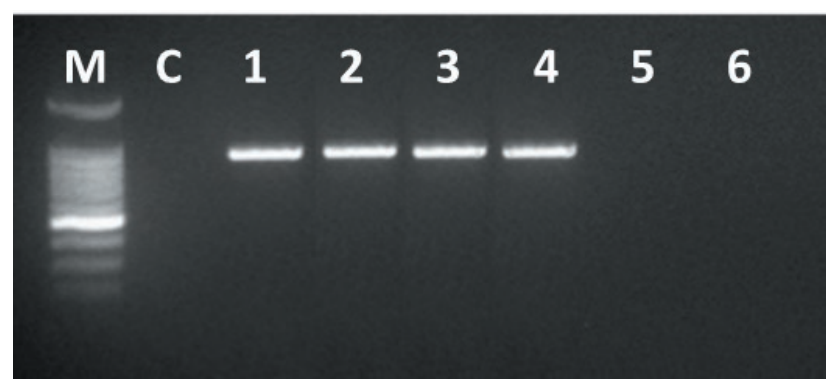

Figure 2. RT-PCR detection of Parietaria mottle virus in symptomatic Phytolacca americana L. leaves. Lanes M, 100 bp DNA ladder; C, control without total RNAs; 1, Positive control (PMoV infected tomato plants); 2 to 4 , symptomatic $P$. americana leaves from three different plants; 5 and 6 , asymptomatic $P$. americana leaves from two different plants. obtained from asymptomatic plants. Sequences obtained from symptomatic P. americana shared $100 \%$ nucleotide similarity, and the corresponding sequence of the isolate Phal was deposited in GenBank (Accession n. MW248388). The Phal sequence shared greatest nucleotide similarity with sequences of the two PMoV tomato isolates from hosts growing nearby: $99.67 \%$ with the tomato isolate 390 (Accession n. MW456562) and 99.78\% similarity with isolate 391A (Accession n. MW456563). This indicated virus movement between the American pokeweed and tomato hosts. These three isolates also clearly grouped in the phylogenetic tree, forming a distinct clade together with the isolates Rucl, identified previously from Diplotaxis tenuifolia (L.) DC., and Fri2, from Capsicum annuum L., in the same Italian region (Parrella et al., 2017; Parrella et al., 2016). Nevertheless, overall phylogenetic grouping showed no clear correlation with host or geographic origin, although the existence of four distinct phylogenetic groups of $\mathrm{PMoV}$ isolates was indicated based on the MP gene (Figure 3). These results confirm those previously obtained and based on the coat protein (CP) phylogenetic relationships of PMoV isolates (Galipienso et al., 2015).

$\mathrm{PMoV}$ is an emerging virus, due to its increasing incidence in tomato and other cultivated plants, such as Cap-

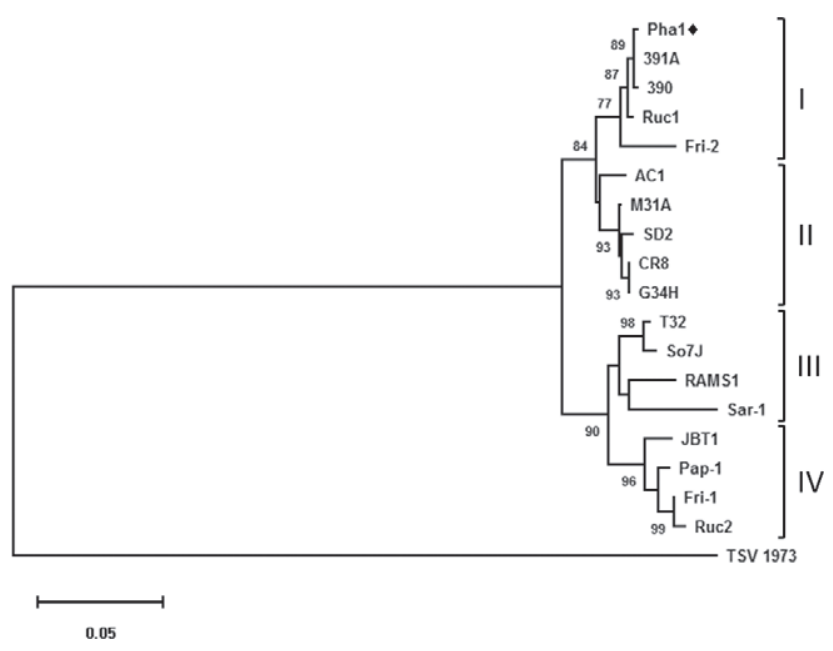

Figure 3. Phylogenetic analysis based on the movement protein (MP) gene of the Parietaria mottle virus (PMoV) isolates examined in this study (Pha1, 390 and 391A), and 15 other PMoV isolates available in GenBank. The accession numbers, isolate names, hosts, geographic origins and years of sampling for each isolate are listed in Table 1. The isolate from Phytolacca americana (Pha1) is indicated in the tree with the symbol $\downarrow$. The phylogenetic tree was constructed using the neighbor joining (NJ) method, with 1000 bootstrap replicates, and genetic distances were calculated by the Tamura three-parameter model using MEGA 7.0. The isolate of tobacco streak virus TSV 1973 (Accession n. JX463336) was used as an outgroup. 
sicum annuum, Diplotaxis tenuifolia, and the ornamental plant Mirabilis jalapa L. (Parrella, 2002; Janssen et al., 2005; Parrella et al., 2016; Parrella et al., 2017; Caruso et al., 2018; Parrella et al., 2020). The discovery of a new natural host of PMoV, i.e. Phytolacca americana, confirms the tendency of the virus to occupy new ecological niches. Within Caryophyllales, Phytolaccaceae are closely related to Nyctaginaceae, the plant family to which Mirabilis jalapa belongs, and this host is another unusual natural host of PMoV (Rettig et al., 1992; Cuénoud et al., 2002; Lee et al., 2013). After the present discovery, further investigations would be useful to increase knowledge of the possible role of American pokeweed as a reservoir of $\mathrm{PMoV}$, and the impacts of epidemics of this pathogen on susceptible crops such as tomato and pepper.

\section{ACKNOWLEDGEMENT}

This research was supported by the Campania Region (Italy), Plan of Phytosanitary Action for 2020, URCOFI project: Unit for coordination and development of surveillance, research, monitoring and training activities for phytosanitary purposes.

\section{LITERATURE CITED}

Bonanomi G., Incerti G., Abd El-Gawad A. M., Sarker T.C., Stinca A., ... Saracino A., 2018. Windstorm disturbance triggers multiple species invasion in a Mediterranean forest. iForest 11: 64-71.

Caruso G., Parrella G., Giorgini M., Nicoletti R., 2018. Crop systems, quality and protection of Diplotaxis tenuifolia. Agriculture 8: 55.

Cuénoud P., Savolainen V., Chatrou L.W., Powell M., Grayer R.J., Chase M.W., 2002. Molecular phylogenetics of Caryophyllales based on nuclear $18 \mathrm{~S}$ rDNA and plastid $\mathrm{rbcL}$, atpB, and matK DNA sequences. American Journal of Botany 89: 132-144.

Galasso G., Conti F., Peruzzi L., Ardenghi N.M.G., Banfi E., ... Bartolucci F., 2018. An updated checklist of the vascular flora alien to Italy. Plant Biosystems 152: 556-592.

Galipienso L., Martinez C., Willemsen A., Alfaro-Férnandez A., Font-San Ambrosio I., ... Rubio L., 2015. Genetic variability and evolutionary analysis of Parietaria mottle virus: role of selection and genetic exchange. Archives of Virology 160: 2611-2616.

Janssen D., Saez E., Segundo E., Martin G., Gil F., Cuadrado I.M., 2005. Capsicum annuum - a new host of Parietaria mottle virus. Plant Pathology 54: 567.
Lee J., Kim S.Y., Park S.H., Ali M.A., 2013. Molecular phylogenetic relationships among members of the family Phytolaccaceae sensu lato inferred from internal transcribed spacer sequences of nuclear ribosomal DNA. Genetics and Molecular Research 12: 45154525.

Lisa V., Ramasso E., Ciuffo M., Roggero P., 1998. Tomato apical necrosis caused by a strain of Parietaria mottle virus. In: Proceedings of the Ninth Conference of the ISHS Vegetable Virus Working Group, Recent Advances in Vegetable Virus research, Torino, 22-27 August. [Unpublished abstracts book], pp. 1-5.

Marchoux G., Parrella G., Gebre-Selassie K., Gognalons P., 1999. Identification de deux ilarvirus sur tomate dans le sud de la France. Phytoma, 522: 53-55.

Parrella G., 2002. First report of Parietaria mottle virus in Mirabilis jalapa. Plant Pathology 51: 401.

Parrella G., Greco B., Troiano E., 2016. Severe symptoms of mosaic and necrosis in bell pepper associated with Parietaria mottle virus in Italy. Plant Disease 100: 1514.

Parrella G., Greco B., Troiano E., 2017. First report of Parietaria mottle virus associated with yellowing disease in Diplotaxis tenuifolia in Italy. Plant Disease 101: 850-851.

Parrella G., Troiano E., Cherchi C., Giordano P., 2020. Severe outbreaks of Parietaria mottle virus in tomato in Sardinia, southern Italy. Journal of Plant Pathology, 102: 915.

Parrella G., 2020. Sources of resistance in wild Solanum germplasm (section Lycopersicon ) to Parietaria mottle virus, an emerging virus in the Mediterranean basin. Plant Pathology 69: 1018-1025.

Ramasso E., Roggero P., Dellavalle G., Lisa V., 1997. Necrosi apicale del pomodoro causata da un Ilarvirus. Informatore Fitopatologico 1: 71-77.

Rettig J.H., Wilson H.D., Manhart J.R., 1992. Phylogeny of the Caryophyllales - gene sequence data. Taxon 41: 201-209.

Roggero P., Ciuffo M., Katis N., Alioto D., Crescenzi A., ... Gallitelli D., 2000. Necrotic disease in tomatoes in Greece and southern Italy caused by a tomato strain of Parietaria mottle virus. Journal of Plant Pathology 82: 159.

Stinca A., Motti R., 2017. Alien plant invasions in Astroni crater, a decades-long unmanaged forest in southern Italy. Atti della Società Toscana di Scienze Naturali, Memorie Serie B 124: 101-108.

Tamura K., Stecher G., Peterson D., Filipski A., Kumar S., 2013. MEGA6: Molecular evolutionary genetics analysis version 6.0. Molecular Biology \& Evolution 30: $2725-2729$. 